\title{
PELATIHAN PERAWATAN DAN PERBAIKAN MESIN POMPA AIR SAWAH UNTUK MENINGKATKAN PRODUKSI PERTANIAN DI DESA GLAGAHAN KECAMATAN PERAK JOMBANG
}

\author{
Sudiyono $^{1 *}$, Urip Mudjiono ${ }^{1}$, Hendro Agus Widodo ${ }^{1}$, Bambang Antoko ${ }^{1}$ \\ Priyo Agus Setiawan', Nopem Ariwiyono ${ }^{1}$ \\ ${ }^{1}$ Politeknik Perkapalan Negeri Surabaya \\ Jl. Teknik Kimia Kampus ITS Sukolilo Surabaya 60111 \\ e-mail: sudiyono2000@yahoo.com \\ diterima tanggal : 19 Juli 2018 disetujui tanggal : 20 November 2018
}

\section{Abstrak}

Sebagai penopang untuk meningkatkan ekonomi desa glagahan adalah pertanian sehingga sebagian besar masyarakat desa glagahan adalah bertani. Hal ini dilakukan sepanjang tahaun atau tiga kali dalam satu tahun perhasilan pertanian tersebut harus tetap sebagai ujung tombak dalam menyangga ekonomi masyarakat desa Glagahan. Kondisi sawah pertaniannya adalah mengandalkan pengairan dengan mengambil air tanah sebagai sumber air untuk mengairi persawahan sepanjang tahun baik pada saat musim hujan terlebih pada saat musim kemarau dengan kontur tanah berpasir, air permukaan mudah hilang.

Untuk menaikkan air tanah butuh mesin pompa air, sehingga setiap pemilik sawah pasti mengoperasikan satu unit pompa air sawah tersebut. Dengan keterbatasan pengetahuan mengenai mesin pompa air sawah tersebut menyebabkan biaya perawatan dan oparasional meningkat seiring sering terjadinya kerusakan pada mesin pompa air tersebut, karena sedikit saja terjadi kerusakan maka harus dibawa ketempat service yang ada di desa tetangga lain yang jaraknya cukup jauh.

Dengan dilakukan pelatihan ini bisa menambah wawasan dan kemampuan bagi petani pemilik pompa air sawah sehingga bisa memperbaiki pompanya sendiri dan tidak perlu lagi ke bengkel atau membayar teknisi untuk memelihara mesin pompa air sawahnya. Setelah dilakukan pelatihan setiap petani akan diberi modul perawatan dan pemeliharaan mesin pompa air sawah yang selama ini petani tidak punya. Dengan berbekal pengetahuan dan peralatan diharapkan kerusakan yang ringan mulai dari sistem pemompaan, sistem bahan bakar, sistem pendingin, sistem pelumas dan overhaul mesin pompa dapat dilakukan sendiri.

Keyword: Maintenance, pompa, overhaul

\begin{abstract}
The economy as a pilar to improve agriculture in the village of Glagahan so that most of Glagahan village are farming. This was experience by farmers three harvests in one years, agricultural income was the spearhead in supporting Glagahan village communities. The condition of farming fields is to rely on irrigation irrigate rice fields. Rice field are flowed for one year in the dry season and rainy seoson because the condition on the paddy field is sand so that the absorption of soil into the water can not last to incres the water that will be channeled to the rice field it requires a water pumping machine, so that each owner of the rice field needs the operation of one water pump unit with limited knowledge about water pumpin machines these field have caused maintenace and operation cost to increse.

There is often damage to pump engine so the farmer can not repair is a slight the demage, it must go to a workshop in a neighborg village, but the distance is quite far. Trainning will add insight and ability for farmer who own water pumps so that can repair own water farmer without having to go to workshop or pay techiniaus to handle water pump machine after traning each farmer will be given a maintenance and maintance module for the water pump that has not been owned by farmer armed with knowledge and equipment it is expected that light damage from pumping systems lubricating systems and overhoul of pumping machine can be done by farmers them selves
\end{abstract}


Keyword: Maintenance, pompa, overhaul

\section{PENDAHULUAN}

\subsection{Latar Belakang}

Desa Glagahan adalah salah satu desa yang berada di kota santri Jombang yang dikelilingi oleh sawah sebagai areal pertanian, sehingga sebagian besar penduduknya bermata pencaharian bercocok tanam / bertani. Untuk bertani sistim irigasinya lebih mengandalkan sumber air tanah dari pada pengairan sungai, karena pengairan sungai tidak bisa menjamin kebutuhan air setiap saat dibutuhankan untuk mengairi tanaman [1]. Tiap desa didaerah Kabupaten Jombang akan tergabung dalam beberapa kelompok tani di setiap desanya. Untuk desa Glagahan juga terbentuk satu kelompok tani yang terdiri dari beberapa anggota pemilik tanah pertanian dibawah pembinaan kepala desa.

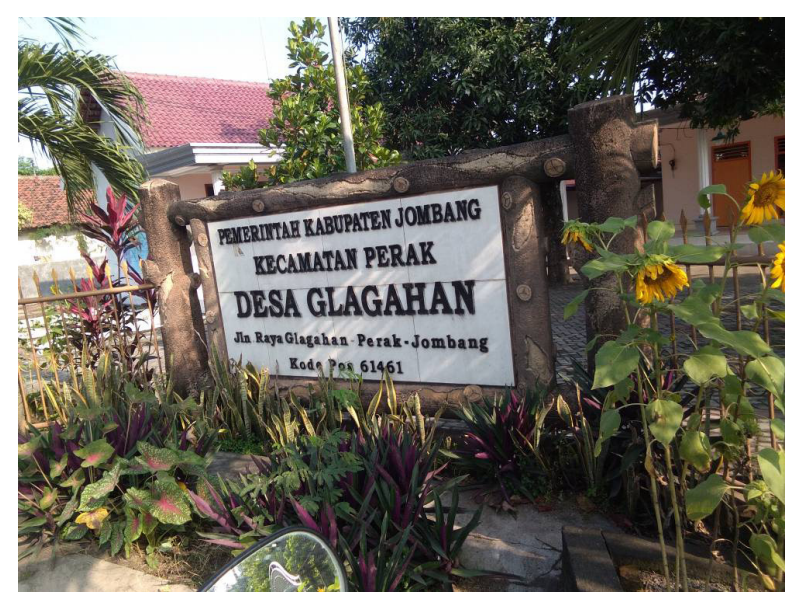

Gambar. 1. Kator desa Glagahan Kecamatan Perak

Desa Glagahan terletak pingir jalan raya Surabaya Jogya, dengan mayoritas pendudunya bercocok tanan atau bermata pencaharian bertani. Dikepalai seorang Kepala Desa dengan beberapa perangkat desa, dengan satu gedung kantor desa dan satu gedung pertemuan yang berada pada satu lokasi. Untuk menunjang operasional desa tersebut dibentu beberapa kelompok tani dengan daerah sesuai pedukuhan masing masing yaitu kelompok tani dukuh Glagahan, kelompok tani dukuh Ploso Duwur dan kelompok tani dukuh Sunberejo [2]. Ketiga kelompok tani ini berada pada desa Glagahan kecamatan Perak.

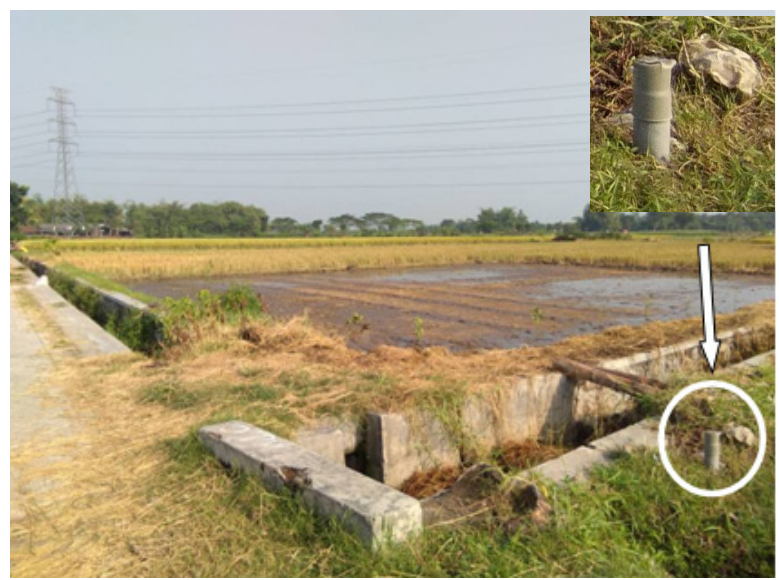

Gambar 2. Saluran irigasi yang kering walaupun pada musim hujan, juga ada sumur pipa buatan dekat saluran irigasi.

Kontur tanah pertanian desa glagahan yang berpasir menyebabkan kebutuhan air pada permukaan tanah besar bila dibandingkan dengan tanah berkontur lengket atau tanah tidak berpasir, sehingga air permukaan cepat kering walaupun sumber air tanah tidak dalam. Sunber air tanah dari permukaan tanah pada kedalaman sekitar 5 sampai 6 meter saja sudah besar, sehingga dipompa sampai 24 jam dengan kapasitas pompa dengan ukuran pipa 3 in tidak habis. Hal ini yang mempermudah system irigasi dengan mengandalkan air tanah untuk mencukupi kebutuhan air baik jenis tanaman padi, jagung maupun kacang tanah

\subsection{Masalah pada Mitra}

Petani pemilik sawah yang tergabung dalam kelompok tani Dukuh Glagahan mengalami permasalahan dalam mengoperasikan perawatan dan perbaikan mesin pompa air yang dioperasikan pada musim kemarau selama ini yaitu setiap mengalami kerusakan harus membawa ke tempat service pompa air yang biasanya harus antri dan tidak bisa selesai dalam satu atau dua hari. Hal ini menyebabkan saat kebutuhan air sawah untuk pertanian baik padi, jagung atau kacang tanah terganggu. Dengan penundaan tersebut menyebabkan hasil produksi pertanian menurun bahkan menyebabkan gagal panen kalau kerusakannya membutuhkan waktu lama. Karena kondisi sawah pertanian desa Glagahan memiliki 
kontur tanah berpasir sehingga kebutuhan air pada musim kemarau harus dialiri air 2 sampai 3 hari sekali. Hal ini sangat tergantung dari pompa air yang bekerja untuk menghisap air tanah untuk pengairan.

Melihat kemampuan Sumber Daya Manusia (SDM) nelayan yang berpendidikan rata - rata SD dan SMP maka untuk sasaran yang dilakukan dalam penyuluhan ini adalah operasional mesin pompa air sawah dan materi - materi praktis yang ditemui dilapangan yang ada kaitannya dengan maintenance dan repear dari motor bensin maupun motor diesel. Hal yang ditemui dilapangan adalah dalam perawatan mesin sering ditak dilakukan secara rutin, tapi dilakukan bila mesin telah mengalami gangguan yang serius dengan memanggil teknisi. Hal ini lah yang mengakibatkan kondisi mesin cepat rusak pada saat dioperasikan, terutama saat digunakan untuk memompa air. Oleh karena itu pengetahuan pemeliharaan mesin ini sangat diperlukan bagi seluruh pemilik pompa air sawah untuk meningkatkan hasil produksi pertaniannya.

Dengan kondisi desa glagahan yang dikelilingi oleh daerah persawahan yang luas, memungkinkan sekali sebagai lumbang panga, tetapi tidak begitu dikukung oleh saluran irigasi pengairan sungai yang memadai karena ada daerah yang lembah sulit untuk membuang air dan daerah yang tinggi mudah airnya hilang. Hal ini memaksa pemilik keseluruhan sawah pada desa Glagahan memiliki mesin pompa air sawah tersebut, dan dioperasikan sepanjang tahun.

Dengan kondisi desa glagahan yang dikelilingi oleh daerah persawahan yang luas, memungkinkan sekali sebagai lumbang panga, tetapi tidak begitu dikukung oleh saluran irigasi pengairan sungai yang memadai karena ada daerah yang lembah
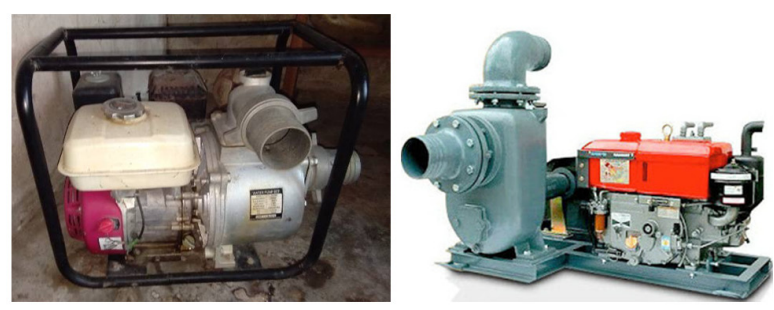

Gambar 3. Mesin Pompa Air dengan motor Bensin dan Motor Diesel
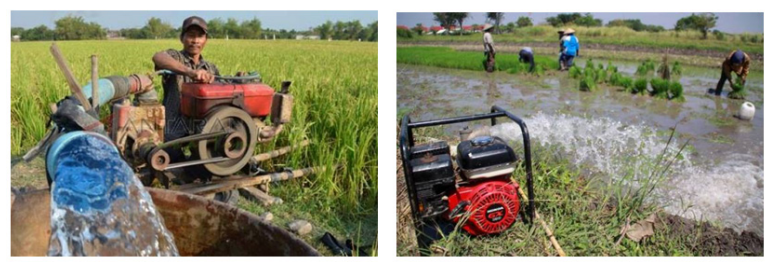

Gambar 4. Pompa air sawah saat beroperasi dengan penggerak motor diesel dan motor bensin

sulit untuk membuang air dan daerah yang tinggi mudah airnya hilang. Hal ini memaksa pemilik keseluruhan sawah pada desa Glagahan memiliki mesin pompa air sawah tersebut, dan dioperasikan sepanjang tahun.

\section{TARGET LUARAN}

\subsection{Solusi yang Ditawarkan}

Setelah dilakukan pelatihan setiap pemilik mesin pompa air akan diberi modul perawatan dan pemeliharaan motor pompa air yang selama ini petani tidak punya. Dengan berbekal pengetahuan dan peralatan diharapkan kerusakan yang ringan mulai dari sistem pemompaan, sistem bahan bakar, sistem pendingin, sistem pelumas dan overhaul mesin dapat dilakukan sendiri [3]. Meningkatkan pengetahuan, keterampilan dan sikap Peserta dalam Perawatan dan Perbaikan Motor penggerak pompa air sawah.

\subsection{Target Luaran}

Sehingga diharapkan keluaran dari program ini adalah :

- Efisien dan efektif dalam mengoperasikan dan merawat mesin motor penggerak pompa air sawah.

- Menumbuh kembangkan minat usaha pertanian untuk meningkatkan produksi pertanian pada kelompok tani desa Glagahan.

- Diharapkan dengan bimbingan yang intensif selama pelaksanaan pengabdian yaitu 6 bulan diharapkan pelaksanaan maintenance dan repair dapat dilakukan sendiri dengan bekal pelatihan dan peralatan yang telah diberikan pada awal pelaksanaan pengabdian pada masing - masing kelompok tani

- Pada akhir program dapat menyisihkan biaya 
- biaya yang selama ini dikeluarkan untuk keuntungan dan menambah penghasilan petani .

\section{METODOLOGI PELAKSANAAN}

\subsection{Persiapan}

Melihat kondisi nelayan tersebut dalam mantenance dan repear mesinpenggerak pompa air sawah, maka untuk meningkan pengetahuan petani dilakukan kegiatan pelatihan perawatan mesin dan cara mengoperasikan mesin. Kegiatan ini dilaksanakan dengan ceramah dan tanya jawab kemudian dilanjutkan dengan demonstrasi perawatan dan perbaikan oleh petani yang dibimbing oleh tim pengabdian juga melakukan praktek langsung overhaul mesin juga perbaikan pompa air sawah.

Demonstrasi perawatan dilakukan di tempat pelatihan yaitu aula kantor desa dengan membawa peralatan

o Satu set mesin diesel 4 silinder 1 buah, dan pressure injektor test

o Satu set mesin bensin

o Satu set pompa air.

o Kompresor

Dari ketiga jenis mesin tersebut nanti dilakukan pembongkaran, pengujian, perawatan dan pemasangan kembali yang dilakukan oleh kurang lebih 5 orang per kelompok dengan 6 kelompok dalam waktu tiga hari. Hasil dari kegiatan ini bertujuan untuk membina kelompok tani desa Glagahan agar dapat melakukan perawatan dan perbaikan mesin dengan prosedur yang benar. Dengan kegiatan ini pula minat masyarakat sangat baik dan petani merasa lebih yakin, benar dan cepat dalam melakukan perawatan dan perbaikan mesin.

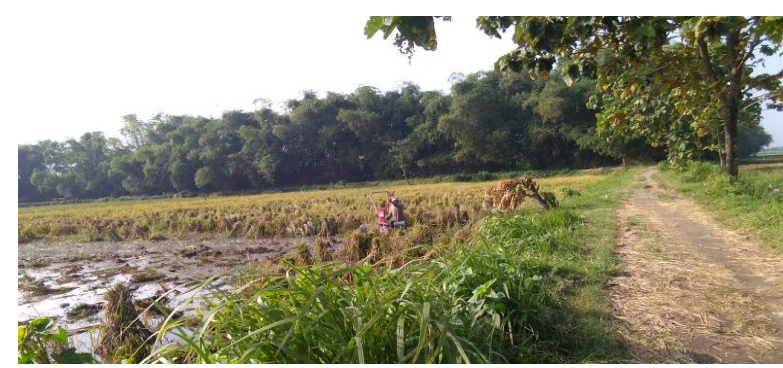

Gambar 4. Sawah daerah dekat perkampungan desa Glagahan sedang proses olah tanah

\subsection{Survey Kelayakan}

Desa Glagahan ini berada pada pinggir jalan raya Surabaya Jogja, tepatnya arah selatan kota Jombang sekita $10 \mathrm{~km}$. Desa Glagahan adalah kawasan persawahan yang $80 \%$ terdiri dari daerah persawahan dan $20 \%$ perunahan. Juga desa Glagahan sebagai lumbung padi yang menyangga kebutuhan beras didaerah Jombang, selaian beberapa desa disekitarnya.

\subsection{Persoalan pada Mitra}

Dengan dioperasikannya mesin pompa air sawah sepanjang tahun /setiap melakukan penanaman baik padi, jagung maupun kacang, maka memungkinkan kerusakan mesin penggerak dan pompa airnya mengalami kerusakan. Dengan terjadinya kerusakan tersebut dan keterbatasan pengetahuan mengenai mesin bensin dan mesin diesel, untuk melakukan perbaikan biasanya dibawa ketempat servis/bengkel yang membutuhkan waktu lama dan biaya yang tinggi. Hal ini akan menganggu proses pengairan tanaman yang harusnya dilakukan, dan nantinya akan mempengaruhi hasil panennya.

\subsection{Implemtasi}

Pelaksanaan pelatihan dilakukan dalam waktu 2 hari dengan jadwal yang telah dibuat dibawah ini. Pada hari pertama berupa perkuliahan tutorial antara team dari PPNS dan Anggota kelompok tani sebagai peserta. Sedangkan hari kedua dibentuk kelompok sebanyak 4 kelompok. Pada hari ke 2 dengan pembagian 2 kelompok perawatan dan perbaikan mesin dan 2 kelompok perawatan sistem pompa air.. Dilanjutkan penyerahan bantuan 1 unit set mesin penggerak beserta sistem pompa dan peralatan perbaikannya.

\subsection{Sosialisasi dan Pelaksanaan Pengabdian}

Untuk pelaksanaan lanjutan dilakukan dengan membentuk kelompok kecil dari seluruh jumlah kelompok tani tersebut, terdiri dari 4 kelompok tani dengan setiap kelompok terdiri dari 5 orang. Untuk setiap kelompok petani akan diberikan satu set tool box yang berisi peralatan maintenance and repair mulai dari set satu kunci pas, satu set kunci ring, kunci momen, filler gauge, palu, obeng 
plus \& minus, tang, dll. Pelaksanaannya akan dipantau selama 8 bulan pelaksanaan pengabdian ini dan sewaktu - waktu ada permasalahan yang dihadapi kelompok tani, maka pendamping akan siap untuk mendatangi kelompok tani dan akan membimbingnya sampai berjalan dengan baik.

\subsection{Hasil Luaran}

Hasil luaran dari pelatihan ini adalah dalam bentuk :

1. Sertifikat yang dikeluarkan oleh pihak pemberi pelatihan (PPNS).

2. Pembentukan unit keci dari kelompok tani (1 unit kelompok 5 orang) sebanyak 4 kelompok unit tani dengan satu set peralatan kunci pas dan kunci ring untuk perawatan mesin yang dibawa ketua kelompok nelayan.

3. Pembimbingan lanjutan dan pemantauan hasil yang dilakukan sebagai pendampingan selama program berlangsung selama 5 bulan.

\section{LAPORAN PELAKSANAAN}

\subsection{Rencana Pelaksanaan Pelatihan}

Dengan jumlah peserta sebanyak 20 prtani dari kelompok tani desa Glagahan yang akan dilaksanakan di rumah salah satu warga dengan ketentuan :

- Dilaksanakan sesuai jadwal 2 kali Hari pertama teori dan hari kedua pelaksanaan praktek.

- Fasilitas menggunakan mesin bensin milik salah satu wargadengan 1 silinder

- Peralatan ukur (micrometer, jangka sorong Dial indicator, pisau perata, fuller dll)

- Dua Set Tool box, kunci sok, Kunci momen dll

- Solar 20 lt untuk tast pompa penggerak mesin diesel dan bensin untuk pompa mesin bensin. Majun $10 \mathrm{~kg}$.

\subsection{Penyerahan Bantuan}

- Peralatan yaitu kunci pas dan kunci ring sebanyak 2 set
- Peralatan kunci shock sebanyak 2 set.

\section{KESIMPULAN DAN SARAN}

\subsection{Kesimpulan}

1. Peserta pelatihan dapat mengoperasikan mesin pompa air sawah dengan benar.

2. Jika mengalami kerusakan mesin pompa aiar sawah dapat memperbaiki sendiri tanpa dibawa ke bengkel.

3. Biaya ke bengkel bisa digunakan untuk kebutuhan yang lain.

4. Sudah mempunyai peralatan untuk melakukan perbaikan mesin pompa dari 24 peserta dengan atau 5 kelompok, karena setiap kelompok memperoleh bantuan peralatan /kunci.

\subsection{Saran}

1. Diharapkan kepedulian masyarakat yang belum memahami melakukan perawatan dan perbaikan sendiri perlu dibimbing antar kelompok yang sudah mampu.

2. Kekurangan peralatan dapat dilakukan dengan membeli secara patungan antar kelompok.

\section{DAFTAR PUSTAKA}

[1] Hanani, Nuhfil, et al. "ANALISIS PEMETAAN DALAM RANGKA DETEKSI DINI KERAWANAN PANGAN TINGKAT DESA." HABITAT 22.1 (2011): 24-38.

[2] Rahayu, Ayyu, Sri Rahayu Utami, and Mochtar Luthfi Rayes. "Karakteristik dan Klasifikasi Tanah pada Lahan Kering dan Lahan yang Disawahkan di Kecamatan Perak Kabupaten Jombang." Jurnal Tanah dan Sumberdaya Lahan 1.2 (2017): 79-87.

[3] HARTANTO, RUDI TRI. Perencanaan Pemeliharaan Mesin Pompa Gilingan Saus Dengan Metode Markov Chain Untuk Minimasi Biaya Pemeliharaan (Studi Kasus Pt. Lombok Gandaria, Unit Maintenance). Diss. Universitas Muhammadiyah Surakarta, 2014. 
Halaman ini sengaja dikosogkan 